\title{
Proceeding
}

Supplementary Issue: Winter Conferences of Sports Science. Costa Blanca Sports Science Events, 24 April 2020. Alicante, Spain.

\section{Testing motor skills, general and special coordinative, in young soccer}

\author{
GAETANO RAIOLA ${ }^{1}$, , GAETANO ALTAVILLA ${ }^{2}$ \\ ${ }^{1}$ Department of Human, Philosophical and Education Sciences, University of Salerno, Italy \\ 2University of Split, Croatia
}

\begin{abstract}
There is need of improvement the quality of the play and the performances continually, above all the motor skills. The tests that have been made to the male young athletes, are easy to administer and are intended to investigate two different motor skills (general coordinative and specific coordinative). The purpose of this study is to monitor and to evaluate the improvement of the performance on a sample of fifteen male young soccer players of 12-13 years old. Method is experimental and has to carry out the usual parameters for monitoring the trainings. Data were collected during eight weeks. All data detected were expressed as average \pm SD on: height (162.8 \pm 3.45$)$, Weight (54.6 \pm 3.21$)$, body mass index $(20.6 \pm 1.72)$ and using some field tests (Harre test, Precision shooting test and Control test of ball). Analysis of statistical data has been conducted with Test-t to check the differences between pre-test and post-test (at the beginning and at the end of a month of specific training). The significant differences have been fixed in $p<.05$. The results show that there is a significant difference between the performance pre and post training, in the three tests conducted. This study analyse and evaluate the reduction or the improvement of the performance, allowing at the coaches of monitor the training process.
\end{abstract}

Keywords: Monitoring; Qualitative aspects; Assessment; Performance.

\section{Cite this article as:}

Raiola, G., \& Altavilla, G. (2020). Testing motor skills, general and special coordinative, in young soccer. Journal of Human Sport and Exercise, 15(2proc), S206-S212. doi:https://doi.org/10.14198//hse.2020.15.Proc2.11

Corresponding author. Department of Human, Philosophical and Education Sciences, University of Salerno, Italy. http://orcid.org/0000-0002-7659-1674

E-mail: graiola@unisa.it

Supplementary Issue: Winter Conferences of Sports Science. Costa Blanca Sports Science Events, 24 April 2020. Alicante, Spain.

JOURNAL OF HUMAN SPORT \& EXERCISE ISSN 1988-5202

(c) Faculty of Education. University of Alicante

doi:10.14198/jhse.2020.15.Proc2.11

S206 | 2020| Proc2 | VOLUME 15

C 2020 University of Alicante 


\section{INTRODUCTION}

Football is defined as a situation sport (Altavilla et al., 2017): sports in which the sports performance cannot be identified in a simplified periodization of the movements that are performed (Raiola \& D'isanto, 2016), due to the presence of one or more opponents (D'Isanto, 2016). In the soccer there are so many rules and so many physical, technical, tactical skills (Dellal et al, 2011) to master, to monitor and to test, utilizing specific tests, also about resistance ( Pastore et al, 2019) and for the young players (Esposito et al 2019). It is widespread in the sport to test one or more athletes, for several reasons: above all allows us to evaluate its potential, its athletic and technical qualities (Safrit, 1990), for example, for a particular skill needed during an intensive sports game such as the soccer: rapidity, agility or coordinative skills (Mathisen \& Danielsen, 2014); but also to set up a correct training methodology, to verify and monitor the effectiveness of training and changes in physical condition (Hughes \& Bartlett, 2002). Both for a coach and for an athlete it is very important to monitor periodically the results of his training programs (Raiola et al., 2018). The tests are a fundamental periodic control tool (Cirillo et al, 2016) very effective and thanks to the analysis of its results and the feedback received it is possible to relate the performance (D'Isanto et al., 2019) with the working strategies, adopting and consequently identifying what may be the best adaptation to be made to the training program (Chiodera et al, 2008) and its relationship to learning's biomechanics skills (Di Domenico et al, 2019). This study involves the use of the following three test: Dexerity circuit (Harre), Precision shooting and Ball control. These have been performed by young soccer players, easy to administer but able to detect the qualitative abilities of players. The tests used were chosen in relation to their simplicity of execution, effectiveness and ease of finding the material needed. Data collection was carried out in the same training session, then was repeated after one month to be able to evaluate possible improvements. The aim of the study is to test and evaluate the motor skills and technical skills in soccer players, monitoring the effects induced after an 8-weeks of a specific training.

\section{METHODS}

The study method is experimental and data was collected between the use of three tests (one general test and two specific tests) before and after eight weeks of training period. During this period players performed three types of exercises prevalently (three times per week): 6vs6 games with up to two touches of ball (30 min.), circuits or exercise on the coordinative skills (30 min.) and exercises on the individual technique as dribble, passing and shot (30 min.). The sample consider 15 male players taking part in provincial championship. The tests that have been performed by young players are three: Dexerity circuit (Harre), Precision shooting and Ball control; these investigate to detect the qualitative abilities of young players. The tests have been performed out by 15 young soccer players who are part of a soccer school in the category under twelve ages. The tests have been performed on a 7-a-side football field and measures 65 meters long and 40 meters wide. Furthermore, as they are under-age, the parents have signed a release in which they declare to take their responsibilities and authorize their children to carry out several tests. All data detected was expressed as average \pm SD on: height, weight, body mass index, Dexerity circuit, Precision shooting, Ball control, have been checked the normality of distribution of the several variables (KS test). The analysis foresees the use the Student t-test to check the differences between the pre and post training, in the three tests conducted, and relative percentages of improvement. The significant differences have been fixed in $p$ $<.05$. All statistical analyses were conducted using IBM SPSS Statistics 23. 


\section{Test motor skills (general)}

Dexerity circuit (Harre)

Harre's dexterity circuit is used to evaluate the result of combining the various coordination skills. The time taken to complete the entire route is recorded. The subject starts standing towards the mat, flips forwards, runs towards the medicine ball and heads for obstacle 1, skips it and then passes it downstairs and again the ball - obstacle 2 - balloon - obstacle 3 - balloon - finish line. The ball when the subject turns should always be on his right and should not be touched while the somersault should only be done once after departure.

\section{Test motor skills (special)}

Precision shooting

6 skittles are lined up at a distance of 1 meter and marked the football areas at 6-8-10-12-14 meters. The space between the central pins is 3 points, those adjacent 2 points and the side 1 point, zero points the external parts. The student kicks the ball firmly trying to make as many points as possible. 3 attempts are made for 3 different distances (10 - 12 - 14 meters). Each student must perform the 3 kicks from the same distance one after the other, while they will go to the next distance when all the students have made their 3 attempts.

\section{Ball control}

A corridor is defined as 20 meters long and 1.50 meters wide. Each player starts with no start signal with the ball placed on the starting line and performs a rectilinear conduction of the ball as quickly as possible. At the end of the conduction the ball must be stopped in the square drawn at the end of the corridor. The ball must not leave the corridor and if it comes out it must be returned to the point where it came out. Each student takes 2 tests with an interval of about 3 - 4 minutes. It is time to the hundredth of a second from the first touch of the ball at the time of the stop in the final square, recording the best of the 2 tests.

Table 1. Anthropometric data.

\begin{tabular}{lcc}
\hline Subjects $(\mathbf{n}=15)$ & M & SD \\
\hline Age $($ year) & 12.5 & 0.89 \\
Height $(\mathrm{cm})$ & 162.8 & 3.45 \\
Weight $(\mathrm{Kg})$ & 54.6 & 3.21 \\
BMI $\left(\mathrm{Kg} / \mathrm{m}^{2}\right)$ & 20.6 & 1.72 \\
\hline
\end{tabular}

\section{RESULTS}

The results show, in the tables 3,5 and 7 , that there are significant improvement between the pre and posttest (after eight week). In fact, in the dexterity circuit test there is a significant difference as shown in the table 3 ; such as in the precision shooting test there is a significant difference, as shown in the table 5 and, finally, also in the ball control test there is a significant difference as shown in the table 7 . These analyse and evaluate of the improvement of the performance allow at the coaches of monitor the training process and to design the training load for an effective performance. The table 2 shows the times detected in the two tests carried out, one month apart between their, for the execution of the Harre dexterity circuit for each individual player. The average of the whole group is of $44.45 \mathrm{sec}$. during the first test and $43.80 \mathrm{sec}$. during the second test. The table 4 shows the score detected in the two tests carried out for the execution of the precision shooting test for each individual player; finally, the table 6 shows the times recorded in the two tests carried out for the execution of the ball control test for each individual player. Making the average of the whole group, 23.48 during the first test and 22.18 during the second test, we can therefore say that the average of the time taken for the test is however decreased with an improvement of all the players. 
Table 2. Times recorded in dexterity circuit test.

\begin{tabular}{lcc}
\hline & $\mathbf{1}^{\circ}$ Test & $\mathbf{2}^{\circ}$ Test (after 8 weeks) \\
\hline 1 & 44.23 & 44.77 \\
2 & 39.99 & 39.68 \\
3 & 46.14 & 45.81 \\
4 & 49.76 & 50.47 \\
5 & 42.07 & 41.14 \\
6 & 51.32 & 50.82 \\
7 & 37.54 & 36.66 \\
8 & 42.38 & 41.23 \\
9 & 40.46 & 39.13 \\
10 & 42.11 & 41.24 \\
11 & 45.31 & 44.32 \\
12 & 44.08 & 43.12 \\
13 & 47.23 & 46.14 \\
14 & 48.02 & 47.21 \\
15 & 46.05 & 45.08 \\
\hline Average & 44.45 & 43.80 \\
\hline
\end{tabular}

Table 3. Difference between the pre and post-test (dexterity circuit).

\begin{tabular}{|c|c|c|c|c|c|c|c|c|}
\hline & \multicolumn{5}{|c|}{ Coupled difference } & \multirow{3}{*}{$t$} & \multirow{3}{*}{ gl } & \multirow{3}{*}{$\mid$ Sign. } \\
\hline & \multirow{2}{*}{ Average } & \multirow{2}{*}{ SD } & \multirow{2}{*}{ Average standard error } & \multicolumn{2}{|c|}{$95 \%$ confidence interval difference } & & & \\
\hline & & & & Inferior & Superior & & & \\
\hline VAR01 VAR02 & 0.65800 & 0.59345 & 0.15323 & 0.32936 & 0.98664 & 4.29 & 14 & .001 \\
\hline
\end{tabular}

Table 4. Points recorded in precision shooting test.

\begin{tabular}{lcc}
\hline & $\mathbf{1}^{\circ}$ Test & $\mathbf{2}^{\circ}$ Test (after 8 weeks) \\
\hline 1 & 14 & 16 \\
2 & 17 & 19 \\
3 & 18 & 19 \\
4 & 10 & 12 \\
5 & 17 & 19 \\
6 & 13 & 14 \\
7 & 19 & 23 \\
8 & 16 & 18 \\
9 & 21 & 22 \\
10 & 17 & 18 \\
11 & 15 & 17 \\
12 & 17 & 19 \\
13 & 17 & 18 \\
14 & 16 & 17 \\
15 & 17 & 18 \\
\hline Average & 16.26 & 17.93 \\
\hline
\end{tabular}


Table 5. Difference between the pre and post-test (precision shooting).

\begin{tabular}{|c|c|c|c|c|c|c|c|c|}
\hline & \multicolumn{5}{|c|}{ Coupled differences } & \multirow{3}{*}{$t$} & \multirow{3}{*}{$g l$} & \multirow{3}{*}{ Sign. } \\
\hline & \multirow[t]{2}{*}{ Average } & \multirow[t]{2}{*}{ SD } & \multirow{2}{*}{$\begin{array}{c}\text { Average standard } \\
\text { error }\end{array}$} & \multicolumn{2}{|c|}{$\begin{array}{c}95 \% \text { confidence interval } \\
\text { difference }\end{array}$} & & & \\
\hline & & & & Inferior & Superior & & & \\
\hline $\begin{array}{l}\text { VAR01 } \\
\text { VAR02 }\end{array}$ & 1.66667 & 0.81650 & 0.21082 & 1.21451 & 2.11883 & 7.906 & 14 & .000 \\
\hline
\end{tabular}

Table 6. Times recorded in the ball control test.

\begin{tabular}{lcc}
\hline & $\mathbf{1}^{\mathbf{0}}$ Test & $\mathbf{2}^{\circ}$ Test (after $\mathbf{8}$ weeks) \\
\hline 1 & 24.51 & 23.90 \\
2 & 19.76 & 18.52 \\
3 & 22.31 & 21.44 \\
4 & 28.33 & 27.11 \\
5 & 24.88 & 24.14 \\
6 & 27.85 & 27.14 \\
7 & 18.54 & 17.98 \\
8 & 22.24 & 21.70 \\
9 & 20.46 & 19.42 \\
10 & 21.34 & 20.36 \\
11 & 22.21 & 21.67 \\
12 & 24.45 & 23.16 \\
13 & 23.86 & 23.11 \\
14 & 22.67 & 22.35 \\
15 & 21.96 & 21.57 \\
\hline Average & 23.02 & 22.24 \\
\hline
\end{tabular}

Table 7. Difference between the pre and post-test (ball control).

\begin{tabular}{|c|c|c|c|c|c|c|c|c|}
\hline & \multicolumn{5}{|c|}{ Coupled differences } & \multirow{3}{*}{$\mathrm{t}$} & \multirow{3}{*}{ gl } & \multirow{3}{*}{ Sign } \\
\hline & \multirow[t]{2}{*}{ Average } & \multirow[t]{2}{*}{ SD } & \multirow{2}{*}{$\begin{array}{l}\text { Average standard } \\
\text { error }\end{array}$} & \multicolumn{2}{|c|}{$\begin{array}{l}95 \% \text { confidence interval } \\
\text { difference }\end{array}$} & & & \\
\hline & & & & Inferior & Superior & & & \\
\hline $\begin{array}{l}\text { VAR01 } \\
\text { VAR02 }\end{array}$ & -0.78667 & 0.30983 & 0.08000 & 0.95825 & -0.61509 & -9.834 & 14 & .000 \\
\hline
\end{tabular}

\section{DISCUSSION AND CONCLUSION}

This study has analysed and evaluate the improvement through the use of tests and monitoring the effects induced after an 8-week of specific training; allowing at the coaches of monitor the training process and to design the training load for an effective performance. During this period players performed three types of exercises prevalently (three times per week): $6 \mathrm{vs} 6$ games with up to two touches of ball (30 min.), circuits or exercise on the coordinative skills (30 min.) and exercises on the individual technique as dribble, passing and shot (30 min.). Specific training hours weekly: fundamentals of individual technique (1h $\left.30^{\prime}\right)$, circuit or exercises on the coordinative skills $\left(1 \mathrm{~h} 30^{\prime}\right)$, game situations or mini matches in confined spaces with two touches ( $1 \mathrm{~h} 30^{\prime}$ ) and monthly total hours (18h $\left.00^{\prime}\right)$. After analysing and interpreting the results, we can confirm that all this is actually feasible, since most of the subjects improved their skills and performances, albeit in 
different and individual way. Through the statistical elaboration of the data, it emerged that following the training sessions carried out in the eight weeks, there was a decent increase in the three different tests (one general coordinative and two specific coordinative skills). The use of the test allows you to have a very effective periodic control and thanks to the analysis of its results and the feedback received it is possible to relate the performance with the work strategies adopted. Therefore, with this operative strategy, it is possible to identify what can be the best adaptations to be made to the training program that is being administered to the athletes. The conclusion obtained is an invitation to further investigations in order to reach the scientific knowledge that must always be the basis of any training methodology.

\section{REFERENCES}

Altavilla, G., D'elia, F., D'isanto, T., Manna, A. (2019). Tests for the evaluation of the improvement of physical fitness and health at the secondary school, Journal of Physical Education and Sport, 19, pp. 1784-1787.

Altavilla G., Riela L., Di Tore P.A., Raiola G., (2017). The physical effort required from professional football players in different playing positions. Journal of Physical Education and Sport, 17(3):20072012.

Chiodera, P., Volta, E., Gobbi, G., Milioli, M.A., Mirandola, P., Bonetti, A., Delsignore, R., Bernasconi, S., Anedda, A., Vitale, M. (2008). Specifically designed physical exercise programs improve children's motor abilities Scandinavian Journal of Medicine and Science in Sports 18(2):179-8. https://doi.org/10.1111/j.1600-0838.2007.00682.x

Cirillo, G., Nughes, E., Acanfora, A., Altavilla, G., D'Isanto, T. (2016). Physical and sport education testing by quantitative and qualitative tools in assessment in senior school: A proposal, Sport Science, 9(suppl 1).

Dellal A, Chamari K, Wong DP, Ahmaidi S, Keller D, Barros R, Bisciotti GN, Carling C, (2011). Comparison of physical and technical performance in European soccer match-play: FA Premier League and La Liga. Eur J Sports Sci., 11:51-59. https://doi.org/10.1080/17461391.2010.481334

Di Domenico, F., Fattore, S., Pignato, S., D'isanto, T. (2019). Relationship between motor learning and reaction capacity in motor task, Journal of Human Sport and Exercise, 14 (Proc4), pp. S1030-S1037. https://doi.org/10.14198/ihse.2019.14.proc4.65

D'Isanto, T., D'Elia, F., Raiola, G., Altavilla, G. (2019). Assessment of sport performance: Theoretical aspects and practical indications, Sport Mont, 17 (1): 79-82.

D'Isanto, T., Di Tore, P. \& Altavilla, G. (2018). Correlation of the anthropometric characteristics and the ability to jump in volleyball, Journal of Human Sport and Exercise, 13(proc2): 393-400. https://doi.org/10.14198/jhse.2018.13.proc2.23

D'Isanto, T. (2016). Pedagogical value of the body and physical activity in childhood. Sport Science, 9 (Supplement 2): 13-18.

Esposito, G., Ceruso, R., D'isanto, T. (2019). Evaluation of some quantitative aspects in the young soccer players training process during puberty, Journal of Physical Education and Sport, 19, pp. 1777-1783.

Hughes, M., \& Bartlett, R. (2002). Special edition on performance analysis. Journal of Sport Sciences, 20:735-737.

Mathisen, G.E., \& Danielsen, K.H. (2014). Effects of speed exercises on acceleration and agility erformance in 13-year-old female soccer players, Journal of Physical Education and Sport, 14(4): 471-474.

Pastore, F., Di Domenico, F., Viscione, I., D'elia, F. (2019). Assessment of aerobic resistance in the young soccer player, Journal of Physical Education and Sport, 19, pp. 1953-1958. 
Raiola, G., D'elia, F., Altavilla, G. (2018). Physical activity and sports sciences between European Research Council and academic disciplines in Italy, Journal of Human Sport and Exercise, 13(proc2): S283-S295. https://doi.org/10.14198/jhse.2018.13.proc2.13

Raiola, G., D'isanto, T. (2016). Assessment of periodization training in soccer, Journal of Human Sport and Exercise, 11 (Proc1): S267-S278. https://doi.org/10.14198/ihse.2016.11.proc1.19

Safrit, M.J. (1990). Untroduction to measurement in physical education and exercise science, 2 nd ed. Times Mirror/Mosby College Publishing, St. Louis.

\section{(c) $(\mathrm{B})(\mathrm{EY}$}

This work is licensed under a Attribution-NonCommercial-NoDerivatives 4.0 International (CC BY-NC-ND 4.0). 